\title{
Stem Cell Therapy: A Prospective Treatment for Alzheimer's Disease
}

\author{
Ji Han Lee', II-Hoan $\mathrm{Oh}^{2}$, and Hyun Kook Lim ${ }^{3 凶}$ \\ ${ }^{1}$ Washington University in St. Louis, St. Louis, MO, USA \\ ${ }^{2}$ The Catholic High-Performance Cell Therapy Center \& Department of Medical Lifescience, The Catholic University of Korea, Seoul, Republic of Korea \\ ${ }^{3}$ Department of Psychiatry, St. Vincent Hospital, College of Medicine, The Catholic University of Korea, Seoul, Republic of Korea
}

\begin{abstract}
Alzheimer's disease $(\mathrm{AD})$ without cure remains as a serious health issue in the modern society. The major neuropathological alterations in $\mathrm{AD}$ are characterized by chronic neuroinflammation and neuronal loss due to neurofibrillary tangles (NFTs) of abnormally hyperphosphorylated tau, plaques of $\beta$-amyloid $(\mathrm{A} \beta)$ and various metabolic dysfunctions. Due to the multifaceted nature of $\mathrm{AD}$ pathology and our limited understanding on its etiology, $\mathrm{AD}$ is difficult to be treated with currently available pharmaceuticals. This unmet need, however, could be met with stem cell technology that can be engineered to replace neuronal loss in AD patients. Although stem cell therapy for AD is only in its development stages, it has vast potential uses ranging from replacement therapy to disease modelling and drug development. Current progress with stem cells in animal model studies offers promising results for the new prospective treatment for $\mathrm{AD}$. This review will discuss the characteristics of $\mathrm{AD}$, current progress in stem cell therapy and remaining challenges and promises in its development.
\end{abstract}

Psychiatry Investig 2016;13(6):583-589

Key Words Alzheimer's disease, Stem cells, Neurogenesis, Transplantation, Disease modelling.

\section{INTRODUCTION}

Alzheimer's disease $(\mathrm{AD})$ is a debilitating neuropsychiatric disorder characterized by the multifaceted decline in cognitive and behavioral functions. Since its discovery by Dr. Alois Alzheimer in 1906, AD has become the most common neurodegenerative form of dementia that is responsible for 50 to $70 \%$ of all dementia cases worldwide. ${ }^{1}$ Over decades of research, many hypotheses on the etiology of AD have been proposed. Early models focused on the functional decline of specific neuronal systems (e.g., cholinergic and GABAergic neurons) in the prefrontal lobe and hippocampus. ${ }^{2-4}$ Today, an established hallmark neuropathologic feature of $\mathrm{AD}$ is neuronal death caused by plaques of extracellular amyloid- $\beta$ $(\mathrm{A} \beta)$ peptides and intracellular neurofibrillary tangles (NFTs) of abnormally hyperphosphorylated tau proteins. ${ }^{5}$ In the past two and half decades, the amyloid cascade hypothesis has received the most support in the field of AD research. ${ }^{6}$ But af-

Received: April 30, 2016 Revised: May 25, 2016

Accepted: May 26, 2016 Available online: July 26, 2016

$\triangle$ Correspondence: Hyun Kook Lim, MD, PhD

Department of Psychiatry, St. Vincent Hospital, College of Medicine, The Catholic University of Korea, 93 Jungbu-daero, Paldal-gu, Suwon 16247, Republic of Korea

Tel: +82-31-249-7150, Fax: +82-31-248-6758, E-mail: drblues@catholic.ac.kr

@ This is an Open Access article distributed under the terms of the Creative Commons Attribution Non-Commercial License (http://creativecommons.org/licenses/bync/3.0) which permits unrestricted non-commercial use, distribution, and reproduction in any medium, provided the original work is properly cited. ter years of clinical examination, existing hypotheses and pharmacological treatments fail to capture the whole picture behind $\mathrm{AD} .^{7}$ With increasing human longevity and growth of the older populations in the society, $\mathrm{AD}$ without cure remains as one of the greatest obstacles in modern medicine. Novel stem cell techniques that target neurogenesis hold potential for treating $\mathrm{AD}$ patients. This review focuses on the current progress, remaining challenges and perspectives in developing stem cell treatment for AD.

\section{AD PATHOGENESIS AND CURRENT TREATMENTS}

The two key biochemical features of $\mathrm{AD}$ are 1) extracellu$\operatorname{lar} \mathrm{A} \beta$ plaques and 2) intracellular NFTs. ${ }^{5,8}$ The formation of $\mathrm{A} \beta$ plaques are a consequence of misguided production of the amyloid peptide. In unaffected individuals, amyloid precursor protein (APP) is cleaved by a-secretase or $\beta$-secretase to yield soluble sAPP $\alpha$ or sAPP $\beta$ peptides, both of which promote neural survival and growth. In $\mathrm{AD}$, another pathway occurs where APP is sequentially cut by $\beta$-secretase and $\gamma$ secretase to produce insoluble $A \beta_{40 / 42}$. $^{9-11}$ These aberrant proteins are rich in $\beta$-sheets in contrast to $\alpha$-helices as in healthy amyloid peptides. ${ }^{12} \mathrm{~A} \beta$ travels through the bloodstream to stimulate additional production of $\mathrm{A} \beta$ in other cells and its neurotoxicity causes death of neurons widely across the cen- 
tral nervous system (CNS) ${ }^{13}$ Intracellular NFTs, on the other hand, are formed by atypical hyperphosphorylation of the tau protein, a microtubule-associated protein (MAP) that supports other cytoskeletal structures and regulates various functions in neurons. ${ }^{8}$ Hyperphosphorylation of intracellular tau is caused by atypical hyperactivation of protein kinases (e.g., PKC and PKA) and leads to cellular apoptosis and neuronal loss. ${ }^{14,15}$ The amyloid cascade hypothesis puts $A \beta$ formation at the pathologic center of $\mathrm{AD}$ progression. ${ }^{6}$

Based on available biochemical and genetic data, physicians generally categorize $\mathrm{AD}$ into two types: early-onset or familial AD (FAD) and late-onset or sporadic AD (SAD). $\mathrm{FAD}$ is a rare form of $\mathrm{AD}$ that affects patients under the age of $65 .{ }^{16}$ Three genes involved in the production of $A \beta-$ amyloid precursor protein (APP), presenilin 1 (PS1) and presenilin 2 (PS2)-have been strongly implicated in this type of AD. ${ }^{17,18}$ Mutations or overexpression of PS1 (chromosome 14) or PS2 (chromosome 1), which comprise the $\gamma$-secretase complex, or APP (chromosome 21) have been linked with $\mathrm{A} \beta$ aggregation and neurodegeneration. ${ }^{19} \mathrm{SAD}$ in contrast occurs in older individuals and accounts for almost $90 \%$ of $\mathrm{AD}$ instances. Apolipoprotein $\mathrm{E}$ (APOE), triggering receptor expressed on myeloid cells 2 (TREM2) and CD33 that are related to tau modification and microglial phagocytosis of $A B$, are the most significantly associated genes to $\mathrm{SAD}$ as discovered in genome-wide association studies (GWAS) ${ }^{20-23}$

In addition to such biochemical changes in the brain, dysfunctions in the metabolism and processing of biomolecules including protein, cholesterol and glucose are also commonly observed in $\mathrm{AD}$ patients. ${ }^{24}$ Proteostasis failure such as the breakdown of the ubiquitin-proteasome pathway triggers uncontrolled cell death and higher formation of NFTs. ${ }^{25-28}$ Inability to process gangliosides aggravates the conversion of non-toxic APP precursors to insoluble, toxic $A \beta{ }^{29,30}$ Furthermore, disrupted glucose metabolism has been shown to cause aberrant synthesis and modification of tau proteins. ${ }^{31,32}$ Metabolic dysfunctions lead to increased levels of cytokines and reactive oxygen species (ROS) and produce deteriorating chronic neuroinflammation in patients with $\mathrm{AD}^{33,34}$

Despite the long years of research and therapeutic trials in $\mathrm{AD}$, an effective treatment is yet to be developed. Current FDAapproved treatments can temporarily delay the progression of $\mathrm{AD}$ by inhibiting neuronal death related proteins and restoring the functions of cholinergic neuronal systems. ${ }^{35,36}$ But even cocktail treatments present insufficient efficacies to handle the rising number $\mathrm{AD}$ patients in the older populations. ${ }^{37,38}$ Pharmaceutical companies around the world shared efforts to develop novel treatment regimes that use passive anti-amyloid immunotherapy or $A \beta$-targeted protein chaperones and they are currently under clinical trial phases. ${ }^{39}$ However, a growing consensus in the field is that current pharmaceuticals are introduced too late in the progression of $\mathrm{AD}$ and that new treatments should target earlier stages in the progression of the disease before widespread neurodegeneration and overt dementia occur. ${ }^{40}$ Stem cell therapy, with its capacity to generate various types of neurons and glial cells, has lately received considerable attention as a potential therapeutic option for reversing neuronal loss in $\mathrm{AD}$, and studies using animal models show promising results. Although long-term investigations are necessary to comprehend its safety and efficacy before human clinical trials, stem cell based therapy holds potential as a next generation treatment for $\mathrm{AD}$.

\section{STEM CELL THERAPY FOR AD}

Treatment of AD with stem cell technology depends on the neurogenesis capacities of stem cells. The strategy is to utilize stem cells to physically replace the neurons that are lost in the neurodegenerative stages in $\mathrm{AD}$. In recent findings, the importance of glial cells and intercellular binding proteins in shaping the external environments of neurons have been suggested. The decline of microglia, astrocytes and oligodendrocytes that support the neuronal networks in the CNS through immune, nutritional and homeostatic mechanisms are correlated with the neuroinflammatory biochemistry of $\mathrm{AD} .^{41,42}$ Additionally, the deterioration of central binding proteins between neurons such as Slitrk and LAR-RPTP contributes to the widespread neuronal loss. ${ }^{43-45}$ Through transplantation or in situ regeneration of lost neurons and key proteins that support them, there is hope to rebuild the integrity of the CNS and to alleviate the decline in cognitive functions in $\mathrm{AD}$ patients. The four types of stem cells that can be generated from the human body - neural stem cells (NSCs), mesenchymal stem cells (MSCs), embryonic stem cells (ECSs) and induced pluripotent stem cells (iPSCs) - each holds unique properties that could be utilized in the stem cell therapy regime in a variety of ways (Figure 1). ${ }^{46}$

\section{NSCs}

Found in small amounts in the mammalian brain, NSCs are multipotent stem cells that can be differentiated into all types of cells found in the CNS ${ }^{46}$ The self-renewal and differentiation potentials of NSCs have been established both in vitro and in vivo. ${ }^{16,47}$ Although limited in their differentiation capacities compared to ESCs and iPSCs, NSCs are the ideal candidates for replacing neurons in the human brain due to their relatively low risks in tumorigenesis and immunogenicity. ${ }^{48,49}$ Potential treatment methods with NSCs involve the induced differentiation of neurons or glial cells through the exposure of specific morphogens followed by overexpression of 


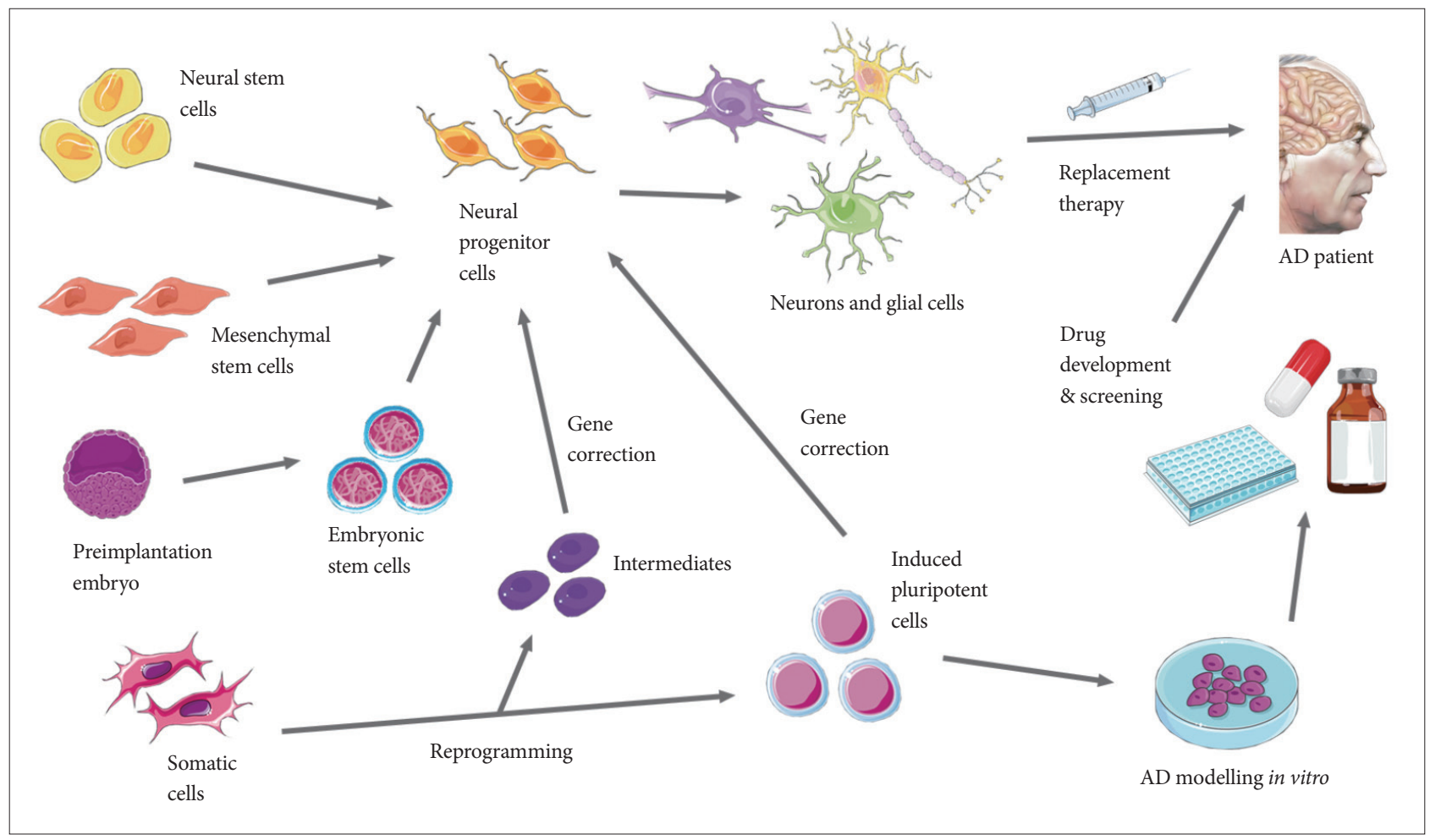

Figure 1. Schematic diagram showing the potential applications of stem cell therapy in Alzheimer's disease.

the healthy cells in patients. In rodent models, the overexpression of NSC-derived cholinergic neurons and choline acetyltransferase (ChAT) restored cognitive performance and synaptic integrity..$^{50,51}$ A limitation of this type of stem cells, however, is their small number in human brain tissue. If their proliferation could be induced and controlled through growth factor exposure, genetic or epigenetic manipulations, NSCs could be developed into an effective addition to current $\mathrm{AD}$ treatments.

\section{MSCs}

MSCs are another multipotent line of stem cells found in the human body (Lanza and Atala, 2014). ${ }^{52}$ They generate diverse cell types at the bone marrow, lungs, umbilical cord, blood, adipose tissue and muscle tissue. ${ }^{53}$ Given their greater availability compared to NSCs, MSCs may be a promising source for therapeutic stem cell treatments. But a drawback is that they can only give rise to a limited number of lineages and display limited survival and short half-lives post-transplantation, particularly depending on the donor cell population and harvest and culture locations. ${ }^{54-56}$ In rodent studies, bone marrow MSCs (BMSCs) and umbilical cord blood MSCs (UCB-MSCs) could be used to generate cholinergic neurons. ${ }^{57-59}$ Treatment using MSCs in mice also contributed to the clearance of abnormal $A \beta$ plaques via microglial activation, prevented neuronal death and increased neuronal dif- ferentiation. ${ }^{60,61}$ In addition, MSCs safely restored cognitive functions such as memory in rodent analyses. ${ }^{61,62}$ MSCs have been shown to further play roles in activating proinflammatory cytokines that are beneficial to the recovery of damaged neuronal environments. ${ }^{63-65}$ Identifying morphogens in differentiating MSCs to a larger range of neural cells would be key in developing MSCs as effective therapeutic treatments.

\section{ESCs}

Extracted from the inner cell mass (ICM) of blastocysts, ESCs are pluripotent stem cells that innately give rise to to all cell types in the development of an embryo ${ }^{66}$ Given their potent differentiation capacities, direct transplantation of ESCs has high risks of teratoma formation and thus strict control and maintenance of stability in differentiation are main areas for improvement with ESC techniques. ${ }^{67,68}$ Several rodent studies suggest that ESC-derived NSCs can be safely transplanted without tumorigenesis, but further research is needed to confirm these results. ${ }^{69,70}$ Moreover, unlike NSCs and MSCs, ESCs carry the added risk of transplantation rejection and immune responses. ${ }^{71,72}$ Although the brain is immune-privileged, the human leukocyte antigen (HLA) profile of donor cells must be considered in transplantation to avoid immune rejection. ${ }^{71}$ Experimentation with human ESCs (hESCs) have so far have been able to successfully produce dopaminergic neurons, spinal motor neurons and astroglial cells. ${ }^{73-77} \mathrm{Re}-$ 
search with hESCs in FDA-approved clinical trials, however, is ethically controversial and must be approached more carefully than other types of stem cells. ${ }^{78,79}$

\section{iPSCs}

iPSCs are an intriguing line of stem cells that are reprogrammed from adult fibroblasts. ${ }^{80}$ In iPSC technology, new stem cells that possess pluripotency comparable to that of hESCs are created through the overexpression of four transcription factors (TFs)-Oct3/4, Sox2, Klf4 and c-Myc. ${ }^{81}$ In 2006, Professor Shinya Yamanaka's research team generated the first iPSCs through retrovirus induced overexpression of these four TFs, but this initial formula exhibited low success rates. ${ }^{82}$ So far, novel methods such as inducing serum starvation and aligning cell cycle rhythms or inducing gene expression through plasmids and adenoviruses have significantly improved the reprogramming techniques. ${ }^{83-85}$ Screening methods for successful reprogramming such as tetraploid complementation have also been developed. ${ }^{86,87}$ Early iPSC protocols solely relied on the complete reprogramming of somatic cells to pluripotent stem cells, but recently developed methods also capture somatic intermediates and transdifferentiate them into induced neural precursor colonies (iNPCs), which are similar in their differentiation potential to NSCs. ${ }^{88}$ In regards to immune reactions, research with iPSCs have shown inconsistent results. Some rodent studies found little or no immune recognition against transplanted iPSCs while others found major histocompatibility complex (MHC) incompatibility of donor and acceptor to elicit immune rejection reactions. ${ }^{22,69,89}$ The unresolved question of immunogenicity with iPSCs must be unraveled before any clinical trials can be started.

\section{Challenges and promises}

Despite the excitement for cell replacement therapy for $\mathrm{AD}$, several challenges remain in its development. An overarching issue in all stem cell based treatments is donor-to-donor variation. Data from transplantation experiments strongly indicate the importance of considering genetic and epigenetic backgrounds of donor cells. In generating neurons and glial cells for transplantation, the genetic defects that cause biochemical symptoms of AD (e.g., APP, PS1, and PS2 in SAD) must be corrected in the donor cells. ${ }^{90}$ This could be achieved by DNA editing with molecular scissors such as CRISPR. Epigenetic memory of donor cells was shown to affect gene expression and cellular stability following transplantation and reprogramming, posing unexpected risks for tumorigenesis. ${ }^{91,92}$ Selecting for purity of donor cells in some studies could reduce heterogeneity and improve functional integrity in the iPSC products. ${ }^{93}$ For this purpose, genome-wide reference maps on epigenetic prints such as DNA methylation are under development. ${ }^{94}$ Another question in stem cell treatment is determining the target for transplantation. Given the widespread neurodegeneration throughout the CNS in $\mathrm{AD}$, it is difficult to determine the ideal location for introducing the new population of neurons while minimizing stability and rejection risks. The hippocampus and lateral ventricles which are known to contain NSCs in the human brain are possible candidates..$^{95}$ Additional setbacks pertaining to ESCs and iPSCs are possibilities of transplantation rejection tumor development. In iPSC research, in vivo or in situ reprogramming have been proposed as solutions. ${ }^{96}$ By reprogramming cells within their endogenous locations, immune responses and risk factors introduced in the in vitro processes could altogether be avoided.

Stem cell technology could also be utilized to model AD to further extend our understanding of the complex disease and to identify potential pharmaceutical agents. Through GWAS and meta-analysis studies, some risk factors and gene candidates in the pathogenesis of $\mathrm{AD}$ have been discovered. ${ }^{97,98}$ But given the multifaceted nature of neurodegernative disorders and the lack of effective pharmaceuticals, our knowledge on $\mathrm{AD}$ progression appears to be inadequate. The amyloid cascade hypothesis is currently the most dominant theory on $\mathrm{AD}$ pathophysiology, but certain cases of $\mathrm{AD}$ patients without $A \beta$ deposition suggest the possibility of a $A D$ mechanism not related to $A \beta$ such as the suspected non-amyloid (or Alzheimer's disease) pathophysiology (SNAP). ${ }^{99}$ Operating on cultured populations from stem cells could be useful in identifying defects responsible for $\mathrm{A} \beta$ and NFTs that current medications fail to target as well as examine the possibility of other modes of pathogenesis. ${ }^{100}$ Cultured neurons from patients' stem cells could also be implemented in screening for drug efficacies and the development of personalized treatment.

\section{CONCLUDING REMARKS}

Stem cell therapy is an expanding area of research that holds vast potential for treating a variety of illnesses such as neurodegenerative disorders. Up to date, stem cell technology is only at its developmental stages but rapid developments and advances indicate its potential uses in direct as well as indirect treatments of $\mathrm{AD}$. Combined with the knowledge from past decades of research on $\mathrm{AD}$, stem cell therapy is a prospective next generation treatment for $\mathrm{AD}$.

\section{Acknowledgments}

This research was supported by Basic Science Research Program through the National Research Foundation of Korea (NRF) funded by the Ministry of Science, ICT \& Future Planning (NRF-2015R1C1A1A02036578). 


\section{REFERENCES}

1. Zhagn L, Li Z. Alzheimer and the discovery of Alzheimer's disease. Zhonghua Yi Shi Za Zhi 2014;44:288-290.

2. Francis PT. The interplay of neurotransmitters in Alzheimer's disease. CNS Spectr 2005;10(11 Suppl 18):6-9.

3. Marczynski TJ. GABAergic deafferentation hypothesis of brain aging and Alzheimer's disease revisited. Brain Res Bull 1998;45:341-379.

4. Palmer AM, Gershon S. Is the neuronal basis of Alzheimer's disease cholinergic or glutamatergic? FASEB J 1990;4:2745-2752.

5. Derouesne C. Alzheimer and Alzheimer's disease: the present enlighted by the past. An historical approach. Psychol Neuropsychiatr Vieil 2008;6:115-128.

6. Reitz C. Alzheimer's disease and the amyloid cascade hypothesis: a critical review. Int J Alzheimers Dis 2012;2012:369808.

7. Imtiaz B, Tolppanen AM, Kivipelto M, Soininen H. Future directions in Alzheimer's disease from risk factors to prevention. Biochem Pharmacol 2014;88:661-670.

8. Khan SS, Bloom GS. Tau: the center of a signaling nexus in Alzheimer's disease. Front Neurosci 2016;10:31.

9. Hahr JY. Physiology of the Alzheimer's disease. Med Hypotheses 2015; 85:944-946

10. Parkin ET, Watt NT, Hussain I, Eckman EA, Eckman CB, Manson JC, et al. Cellular prion protein regulates beta-secretase cleavage of the Alzheimer's amyloid precursor protein. Proc Natl Acad Sci U S A 2007;104:11062-11067.

11. Ronicke R, Mikhaylova M, Ronicke S, Meinhardt J, Schroder UH, Fandrich $\mathrm{M}$, et al. Early neuronal dysfunction by amyloid beta oligomers depends on activation of NR2B-containing NMDA receptors. Neurobiol Aging 2011;32:2219-2228.

12. Berthelot $\mathrm{K}$, Cullin $\mathrm{C}$, Lecomte $\mathrm{S}$. What does make an amyloid toxic: morphology, structure or interaction with membrane? Biochimie 2013; 95:12-19.

13. Pallas M, Camins A. Molecular and biochemical features in Alzheimer's disease. Curr Pharm Des 2006;12:4389-4408.

14. Dickey CA, Koren J, Zhang YJ, Xu YF, Jinwal UK, Birnbaum MJ, et al. Akt and CHIP coregulate tau degradation through coordinated interactions. Proc Natl Acad Sci U S A 2008;105:3622-3627.

15. Lindwall G, Cole RD. Phosphorylation affects the ability of tau protein to promote microtubule assembly. J Biol Chem 1984;259:5301-5305.

16. Amemori T, Jendelova P, Ruzicka J, Urdzikova LM, Sykova E. Alzheimer's disease: mechanism and approach to cell therapy. Int J Mol Sci 2015;16:26417-26451.

17. Bateman RJ, Aisen PS, De Strooper B, Fox NC, Lemere CA, Ringman JM, et al. Autosomal-dominant Alzheimer's disease: a review and proposal for the prevention of Alzheimer's disease. Alzheimers Res Ther 2011;3:1.

18. Parihar MS, Hemnani T. Alzheimer's disease pathogenesis and therapeutic interventions. J Clin Neurosci 2004;11:456-467.

19. Cacquevel M, Aeschbach L, Houacine J, Fraering PC. Alzheimer's disease-linked mutations in presenilin-1 result in a drastic loss of activity in purified gamma-secretase complexes. PLoS One 2012;7:e35133.

20. Bradshaw EM, Chibnik LB, Keenan BT, Ottoboni L, Raj T, Tang A, et al. CD33 Alzheimer's disease locus: altered monocyte function and amyloid biology. Nat Neurosci 2013;16:848-850.

21. Griciuc A, Serrano-Pozo A, Parrado AR, Lesinski AN, Asselin CN, Mullin K, et al. Alzheimer's disease risk gene CD33 inhibits microglial uptake of amyloid beta. Neuron 2013;78:631-643.

22. Jones B. Alzheimer disease: TREM2 linked to late-onset AD. Nat Rev Neurol 2013;9:5.

23. Selfridge JE, E L, Lu J, Swerdlow RH. Role of mitochondrial homeostasis and dynamics in Alzheimer's disease. Neurobiol Dis 2013;51:3-12.

24. Saharan S, Mandal PK. The emerging role of glutathione in Alzheimer's disease. J Alzheimers Dis 2014;40:519-529.

25. Resende R, Moreira PI, Proenca T, Deshpande A, Busciglio J, Pereira
C, et al. Brain oxidative stress in a triple-transgenic mouse model of Alzheimer disease. Free Radic Biol Med 2008;44:2051-2057.

26. Schroder M, Kaufman RJ. The mammalian unfolded protein response. Annu Rev Biochem 2005;74:739-789.

27. Taylor RC, Dillin A. Aging as an event of proteostasis collapse. Cold Spring Harb Perspect Biol 2011;3.

28. Urra H, Dufey E, Lisbona F, Rojas-Rivera D, Hetz C. When ER stress reaches a dead end. Biochim Biophys Acta 2013;1833:3507-3517.

29. Ghosal K, Vogt DL, Liang M, Shen Y, Lamb BT, Pimplikar SW. Alzheimer's disease-like pathological features in transgenic mice expressing the APP intracellular domain. Proc Natl Acad Sci U S A 2009;106: 18367-18372.

30. Kakio A, Nishimoto SI, Yanagisawa K, Kozutsumi Y, Matsuzaki K. Cholesterol-dependent formation of GM1 ganglioside-bound amyloid beta-protein, an endogenous seed for Alzheimer amyloid. J Biol Chem 2001;276:24985-24990.

31. Jacobsen KT, Iverfeldt K. O-GlcNAcylation increases non-amyloidogenic processing of the amyloid-beta precursor protein (APP). Biochem Biophys Res Commun 2011;404:882-886.

32. Liu F, Iqbal K, Grundke-Iqbal I, Hart GW, Gong CX. O-GlcNAcylation regulates phosphorylation of tau: a mechanism involved in Alzheimer's disease. Proc Natl Acad Sci U S A 2004;101:10804-10809.

33. Federico A, Cardaioli E, Da Pozzo P, Formichi P, Gallus GN, Radi E. Mitochondria, oxidative stress and neurodegeneration. J Neurol Sci 2012;322:254-262.

34. Luque-Contreras D, Carvajal K, Toral-Rios D, Franco-Bocanegra D, Campos-Peña V. Oxidative stress and metabolic syndrome: cause or consequence of Alzheimer's disease? Oxid Med Cell Longev 2014;2014: 497802.

35. Confaloni A, Tosto G, Tata AM. Promising therapies for Alzheimer's disease. Curr Pharm Des 2016;22:2050-2056.

36. Stella F, Radanovic M, Canineu PR, de Paula VJ, Forlenza OV. Antidementia medications: current prescriptions in clinical practice and new agents in progress. Ther Adv Drug Saf 2015;6:151-165.

37. Godyn J, Jonczyk J, Panek D, Malawska B. Therapeutic strategies for Alzheimer's disease in clinical trials. Pharmacol Rep 2016;68:127-138.

38. Waite LM. Treatment for Alzheimer's disease: has anything changed? Aust Prescr 2015;38:60-63.

39. Ankarcrona M, Winblad B, Monteiro C, Fearns C, Powers ET, Johansson J, et al. Current and future treatment of amyloid diseases. J Intern Med 2016;280:177-202.

40. Tong LM, Fong H, Huang Y. Stem cell therapy for Alzheimer's disease and related disorders: current status and future perspectives. Exp Mol Med 2015;47:e151.

41. Zhang F, Jiang L. Neuroinflammation in Alzheimer's disease. Neuropsychiatr Dis Treat 2015;11:243-256.

42. Zhang Y, Li P, Feng J, Wu M. Dysfunction of NMDA receptors in Alzheimer's disease. Neurol Sci 2016 Inpress.

43. Aruga J, Yokota N, Mikoshiba K. Human SLITRK family genes: genomic organization and expression profiling in normal brain and brain tumor tissue. Gene 2003;315:87-94.

44. Han KA, Jeon S, Um JW, Ko J. Emergent Synapse Organizers: LARRPTPs and their Companions. Int Rev Cell Mol Biol 2016;324:39-65.

45. Um JW, Ko J. LAR-RPTPs: synaptic adhesion molecules that shape synapse development. Trends Cell Biol 2013;23:465-475.

46. Martinez-Morales PL, Revilla A, Ocana I, Gonzalez C, Sainz P, McGuire D, et al. Progress in stem cell therapy for major human neurological disorders. Stem Cell Rev 2013;9:685-699.

47. Bond AM, Ming GL, Song H. Adult mammalian neural stem cells and neurogenesis: five decades later. Cell Stem Cell 2015;17:385-395.

48. Kim SU, Lee HJ, Kim YB. Neural stem cell-based treatment for neurodegenerative diseases. Neuropathology 2013;33:491-504.

49. Oliveira AA Jr, Hodges HM. Alzheimer's disease and neural transplantation as prospective cell therapy. Curr Alzheimer Res 2005;2:79-95.

50. Park D, Yang YH, Bae DK, Lee SH, Yang G, Kyung J, et al. Improve- 
ment of cognitive function and physical activity of aging mice by human neural stem cells over-expressing choline acetyltransferase. Neurobiol Aging 2013;34:2639-2646.

51. Xuan AG, Long DH, Gu HG, Yang DD, Hong LP, Leng SL. BDNF improves the effects of neural stem cells on the rat model of Alzheimer's disease with unilateral lesion of fimbria-fornix. Neurosci Lett 2008;440: 331-335.

52. Lanza RP, Atala A. Essentials of Stem Cell Biology, Second Edition. Amsterdam: Elsevier/Academic Press; 2014.

53. Phinney DG, Prockop DJ. Concise review: mesenchymal stem/multipotent stromal cells: the state of transdifferentiation and modes of tissue repair--current views. Stem Cells 2007;25:2896-2902.

54. Bongso A, Fong CY, Gauthaman K. Taking stem cells to the clinic: major challenges. J Cell Biochem 2008;105:1352-1360.

55. Oh IH. Mesenchymal stromal cells: new insight on their identity and potential role in cell therapy. Korean J Hematol 2010;45:219-221.

56. Martin I, De Boer J, Sensebe L; MSC Committee of the International Society for Cellular Therapy. A relativity concept in mesenchymal stromal cell manufacturing. Cytotherapy 2016;18:613-620.

57. Sun C, Shao J, Su L, Zhao J, Bi J, Yang S, et al. Cholinergic neuron-like cells derived from bone marrow stromal cells induced by tricyclodecane-9-yl-xanthogenate promote functional recovery and neural protection after spinal cord injury. Cell Transplant 2013;22:961-975.

58. Wu QY, Li J, Feng ZT, Wang TH. Bone marrow stromal cells of transgenic mice can improve the cognitive ability of an Alzheimer's disease rat model. Neurosci Lett 2007;417:281-285.

59. Zhang L, Tan X, Dong C, Zou L, Zhao H, Zhang X, et al. In vitro differentiation of human umbilical cord mesenchymal stem cells (hUCMSCs), derived from Wharton's jelly, into choline acetyltransferase (ChAT)-positive cells. Int J Dev Neurosci 2012;30:471-477.

60. Takata K, Kitamura Y, Yanagisawa D, Morikawa S, Morita M, Inubushi T, et al. Microglial transplantation increases amyloid-beta clearance in Alzheimer model rats. FEBS Lett 2007;581:475-478.

61. Yun HM, Kim HS, Park KR, Shin JM, Kang AR, il Lee K, et al. Placenta-derived mesenchymal stem cells improve memory dysfunction in an Abeta1-42-infused mouse model of Alzheimer's disease. Cell Death Dis 2013;4:e958.

62. Kim KS, Kim HS, Park JM, Kim HW, Park MK, Lee HS, et al. Longterm immunomodulatory effect of amniotic stem cells in an Alzheimer's disease model. Neurobiol Aging 2013;34:2408-2420.

63. Ding H, Zhang H, Ding H, Li D, Yi X, Ma X, et al. Transplantation of placenta-derived mesenchymal stem cells reduces hypoxic-ischemic brain damage in rats by ameliorating the inflammatory response. Cell Mol Immunol 2015 Inpress.

64. Park HW, Moon HE, Kim HS, Paek SL, Kim Y, Chang JW, et al. Human umbilical cord blood-derived mesenchymal stem cells improve functional recovery through thrombospondin1, pantraxin3, and vascular endothelial growth factor in the ischemic rat brain. J Neurosci Res 2015;93:1814-1825.

65. Zhou X, Gu J, Gu Y, He M, Bi Y, Chen J, et al. Human umbilical cordderived mesenchymal stem cells improve learning and memory function in hypoxic-ischemic brain-damaged rats via an IL-8-mediated secretion mechanism rather than differentiation pattern induction. Cell Physiol Biochem 2015;35:2383-2401.

66. Lerou P. Embryonic stem cell derivation from human embryos. Methods Mol Biol 2011;767:31-35.

67. Kooreman NG, Wu JC. Tumorigenicity of pluripotent stem cells: biological insights from molecular imaging. J R Soc Interface 2010;7 (Suppl 6):S753-S763.

68. Ratajczak MZ, Jadczyk T, Pedziwiatr D, Wojakowski W. New advances in stem cell research: practical implications for regenerative medicine. Pol Arch Med Wewn 2014;124:417-426.

69. Araki R, Uda M, Hoki Y, Sunayama M, Nakamura M, Ando S, et al. Negligible immunogenicity of terminally differentiated cells derived from induced pluripotent or embryonic stem cells. Nature 2013;494:
100-104.

70. Tang J, Xu H, Fan X, Li D, Rancourt D, Zhou G, et al. Embryonic stem cell-derived neural precursor cells improve memory dysfunction in Abeta(1-40) injured rats. Neurosci Res 2008;62:86-96.

71. Chen H, Li Y, Lin X, Cui D, Cui C, Li H, et al. Functional disruption of human leukocyte antigen II in human embryonic stem cell. Biol Res 2015;48:59.

72. Jin $\mathrm{X}$, Lin $\mathrm{T}, \mathrm{Xu}$ Y. Stem cell therapy and immunological rejection in animal models. Curr Mol Pharmacol 2015 Inpress.

73. Chambers SM, Fasano CA, Papapetrou EP, Tomishima M, Sadelain M, Studer L. Highly efficient neural conversion of human ES and iPS cells by dual inhibition of SMAD signaling. Nat Biotechnol 2009;27:275-280.

74. Cho MS, Lee YE, Kim JY, Chung S, Cho YH, Kim DS, et al. Highly efficient and large-scale generation of functional dopamine neurons from human embryonic stem cells. Proc Natl Acad Sci U S A 2008;105:33923397.

75. Krencik R, Weick JP, Liu Y, Zhang ZJ, Zhang SC. Specification of transplantable astroglial subtypes from human pluripotent stem cells. Nat Biotechnol 2011;29:528-534.

76. Kriks S, Shim JW, Piao J, Ganat YM, Wakeman DR, Xie Z, et al. Dopamine neurons derived from human ES cells efficiently engraft in animal models of Parkinson's disease. Nature 2011;480:547-551.

77. Lee H, Shamy GA, Elkabetz Y, Schofield CM, Harrsion NL, Panagiotakos G, et al. Directed differentiation and transplantation of human embryonic stem cell-derived motoneurons. Stem Cells 2007;25:1931-1939.

78. Auerbach SB. Taking another look at the definition of an embryo: President Bush's criteria and the problematic application of federal regulations to human embryonic stem cells. Emory Law J 2002;51:1557-1604.

79. Liras A. Future research and therapeutic applications of human stem cells: general, regulatory, and bioethical aspects. J Transl Med 2010; $8: 131$.

80. Takahashi K, Yamanaka S. A developmental framework for induced pluripotency. Development 2015;142:3274-3285.

81. Yu J, Vodyanik MA, Smuga-Otto K, Antosiewicz-Bourget J, Frane JL, Tian S, et al. Induced pluripotent stem cell lines derived from human somatic cells. Science 2007;318:1917-1920.

82. Fan X, Sun D, Tang X, Cai Y, Yin ZQ, Xu H. Stem-cell challenges in the treatment of Alzheimer's disease: a long way from bench to bedside. Med Res Rev 2014;34:957-978.

83. Chen M, Huang J, Yang X, Liu B, Zhang W, Huang L, et al. Serum starvation induced cell cycle synchronization facilitates human somatic cells reprogramming. PLoS One 2012;7:e28203.

84. Okita K, Nakagawa M, Hyenjong H, Ichisaka T, Yamanak S. Generation of mouse induced pluripotent stem cells without viral vectors. Science 2008;322:949-953.

85. Stadtfeld M, Nagaya M, Utikal J, Weir G, Hochedlinger K. Induced pluripotent stem cells generated without viral integration. Science 2008;322:945-949.

86. Bilic J, Izpisua Belmonte JC. Concise review: induced pluripotent stem cells versus embryonic stem cells: close enough or yet too far apart? Stem Cells 2012;30:33-41.

87. Boland MJ, Hazen JL, Nazor KL, Rodriguez AR, Gifford W, Martin G, et al. Adult mice generated from induced pluripotent stem cells. Nature 2009;461:91-94.

88. Kim J, Efe JA, Zhu S, Talantova M, Yuan X, Wang S, et al. Direct reprogramming of mouse fibroblasts to neural progenitors. Proc Natl Acad Sci U S A 2011;108:7838-7843.

89. Zhao T, Zhang ZN, Rong Z, Xu Y. Immunogenicity of induced pluripotent stem cells. Nature 2011;474:212-215.

90. Yagi T, Ito D, Okada Y, Akamatsu W, Nihei Y, Yoshizaki T, et al. Modeling familial Alzheimer's disease with induced pluripotent stem cells. Hum Mol Genet 2011;20:4530-4539.

91. Chin MH, Mason MJ, Xie W, Volinia S, Singer M, Peterson C, et al. Induced pluripotent stem cells and embryonic stem cells are distinguished by gene expression signatures. Cell Stem Cell 2009;5:111-123. 
92. Marchetto MC, Yeo GW, Kainohana O, Marsala M, Gage FH, Muotri AR. Transcriptional signature and memory retention of human-induced pluripotent stem cells. PLoS One 2009;4:e7076.

93. Yuan SH, Martin J, Elia J, Flippin J, Paramban RI, Hefferan MP, et al. Cell-surface marker signatures for the isolation of neural stem cells, glia and neurons derived from human pluripotent stem cells. PLoS One 2011;6:e17540.

94. Bock C, Kiskinis E, Verstappen G, Gu H, Boulting G, Smith ZD, et al. Reference Maps of human ES and iPS cell variation enable highthroughput characterization of pluripotent cell lines. Cell 2011;144:439452.

95. Qu T, Brannen CL, Kim HM, Sugaya K. Human neural stem cells improve cognitive function of aged brain. Neuroreport 2001;12:1127-1132.

96. Zhou Q, Brown J, Kanarek A, Rajagopal J, Melton DA. In vivo reprogramming of adult pancreatic exocrine cells to beta-cells. Nature 2008;
455:627-632.

97. Puthiyedth N, Riveros C, Berretta R, Moscato P. Identification of differentially expressed genes through integrated study of alzheimer's disease affected brain regions. PLoS One 2016;11:e0152342.

98. Roostaei T, Nazeri A, Felsky D, De Jager PL, Schneider JA, Pollock BG, et al. Genome-wide interaction study of brain beta-amyloid burden and cognitive impairment in Alzheimer's disease. Mol Psychiatry 2016 Inpress.

99. Jack CR Jr, Knopman DS, Chetelat G, Dickson D, Fagan AM, Frisoni GB, et al. Suspected non-Alzheimer disease pathophysiology - concept and controversy. Nat Rev Neurol 2016;12:117-124.

100. Kondo T, Asai M, Tsukita K, Kutok Y, Ohsawa Y, Sunada Y, et al. Modeling Alzheimer's disease with iPSCs reveals stress phenotypes associated with intracellular Abeta and differential drug responsiveness. Cell Stem Cell 2013;12:487-496. 